\title{
THE GRAIN PRODUCTS SUBCOMPLEX OF AGRO INDUSTRIAL COMPLEX OF UKRAINE: STRATEGY OF VALUE ADDED MANAGEMENT
}

\author{
Olexander SVITOVYI ${ }^{1}$ \\ Uman National University of Horticulture, Ukraine
}

\begin{abstract}
The purpose of the paper is substantiation of ways to improve strategic value added management of grain products subcomplex of Ukraine agro-industrial complex. Methodology. The study is based on the monographic method and the use of statistical information to confirm the conclusion that the management strategy of value added can be the basis for the development of grain products subcomplex. Results showed that one of the strategic objectives of grain products subcomplex is the growth of production through the introduction of resource-saving technologies, as well as the export of products with high added value. Within the grain products subcomplex special attention should be paid to vertical and horizontal integration. Integration in grain products subcomplex AIC of Ukraine, so and cooperation, will contribute to increase added value and does not require intermediaries. To achieve greater added value in grain products subcomplex, an important role should play the strategy development at the state level. State regulation of this process should be based on improving tax and customs legislation in relation to the industries of grain products subcomplex, as well as involves: an increase in state support of grain producers and processing industries; increase of government order and stabilizing of purchase prices; partial indemnification and reduction of prices of the purchased resources; expansion of leasing and others like that. Practical implication. The correct choice of strategy in value added management in a grain products subcomplex will provide AIC of Ukraine the intensive development. It will be instrumental in transfer of agro-industrial production from raw material in production with a high value added. Value/originality. This study will help to better understand the conditions and factors that influence the increase of value added in the grain products subcomplex AIC of Ukraine in the strategic aspect.
\end{abstract}

Key words: grain products subcomplex, value added, strategic management, grain processing, profit.

JEL Classification: E64, Q18, 012

\section{Introduction}

To a large extent, the future stable development of the industries of grain products subcomplex AIC of Ukraine is possible in case of production optimization and achieve maximum of value added. To solve this problem for the long term, you need to choose the right strategy in the management of added value. This problem is insufficiently studied in scientific literature, therefore, requires further research. The aim of this work is substantiation of ways of perfection of strategic value added management of grain products subcomplex AIC of Ukraine. Scientifically research the tasks of this article are the following: to define basic directions of strategic development of grain products subcomplex AIC of Ukraine in relation to the increase of value added; to analyze the commodity structure of export and import of grain and products of his processing; disclose the functions of strategic management value added. The study is based on monographic method and the use of statistical information to confirm the conclusion that the management strategy value-added can be the basis for the development of grain products subcomplex. The article presentation logic of the studied material determined from the analysis of the current state of development of grain products subcomplex and the correct choice of strategy in the added value management. Identified export opportunities of grain products subcomplex. On this basis identified the main directions of improving the strategic management of value added in grain products subcomplex of AIC of Ukraine.

\section{The choice of strategy in the management of value added}

Increase of size of value added in the grain products subcomplex as most subcomplex AIC of Ukraine is an important task for development of economy of market type. In addition, the maximization of value added in subcomplex provides for the process in the long term.

Corresponding author:

${ }^{1}$ Department of Management of Organizations, Uman National University of Horticulture.

E-mail: svitovyy@rambler.ru 
That is, this requires a corresponding strategy. Strategy the art of manage socio-economic processes, determining the main direction in achieving the final result (Zavadsky, 2006). Goncharov S. M. and Kushnir N. B. have described the strategy as the basic forms and methods promising actions for addressing the main problems with the implementation of strategic programs, achievement of important, future strategic goals (Goncharov, 2009). To our opinion, improvement of strategic management of value added in the grain products subcomplex of AIC of Ukraine will enable achievement of steady increase of its size during the protracted period. This will be a weighty contribution to the development of the grain industry of agriculture and industries, which use in the production of grain and its processing products.

Choosing the right strategy in the management of value added in the grain products subcomplex will provide agroindustrial complex of Ukraine intensive development, the gradual transformation of agricultural production of the raw material in the production of high value added.

Some domestic scientists assert that Ukraine develops not Euro-American and not especially Latino-American model, but the original own combined model of development of agriculture, for which characteristic both separate lines two models marked higher and own substantial features. Scientists notice thus, that although modern and perspective strategy of development of agriculture of the European countries is directed on to development of farms, however is and large-scale companies in these countries to have arisen (Andriichuk, 2013). Consequently, it is necessary in our country to develop the own model of agro industrial production, including grain products subcomplex.

The improvement of strategic management of value added in grain products subcomplex of AIC can positively influence on the increase of the productivity of graincrops, improvement of quality of grain, decline of his prime price. Ambrosov V. Y. noted that the calculations carried out taking into account the basic crop capacity of cereal crops of France and the United States and adapted to conditions of Ukraine, the conservation of acreage on the actual level with the growth of productivity will give the opportunity for the gross grain harvest in the country to 108,8 million tonnes, of which up 86.8 million tonnes can be implemented for export. A scientist asserts farther, that motion to 100 million $t$ must be self-weighted, successive, system and complex. On next years it is necessary to create a material and technical base and proper infrastructure for a stable receipt and storage 50-60 million tonnes of grains (Ambrosov, 2013). Sharing the opinion of the scientist, we, nevertheless, along with the development of infrastructure of grain farming, have defined by the need to increase the power of enterprises for processing of grain and production of finished products. Basic directions of strategic development of grain products subcomplex of AIC of Ukraine in relation to the increase of value added, offered by us, shown in Fig. 1.

To increase value added in the industries of grain products subcomplex is necessary primarily to identify promising products and to optimize production. Here you need to consider what products of subcomplex, which buys the end user should have the greater value added. That is, grain and products of its processing should be realized in the best condition that will maximize the value added. Increase the capacity of processing industries of grain products subcomplex will allow producing more semifinished and finished products of grain, which contain higher value added.

It is not possible to achieve a greater magnitude of value added without the introduction of resource-saving

Strategy of development of grain products subcomplex of AIC of Ukraine in relation to the increase of value added

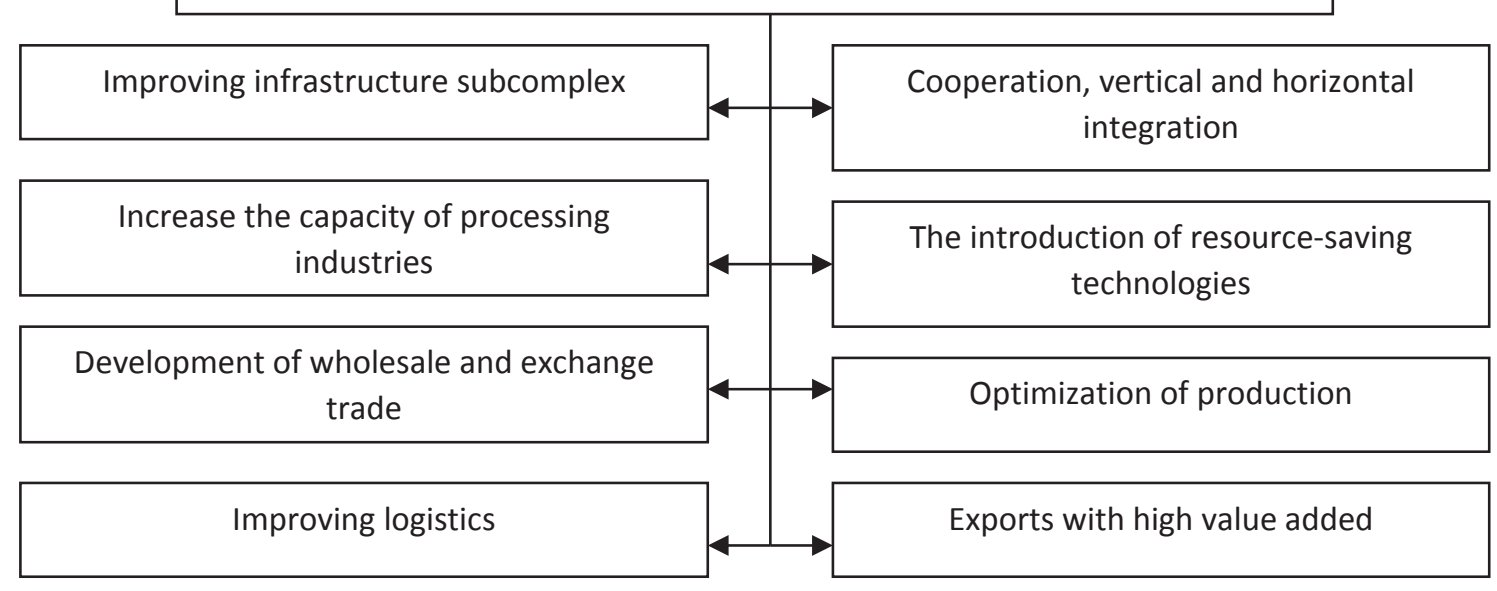

Fig. 1. The main directions of strategic development of grain products subcomplex of Ukraine regarding the increase of value added

Source: own research 
technologies and reducing material costs. This requires an appropriate system of machines and the reliable provision of material resources. Therefore, the improvement of logistics is an element of achieving greater added value. Proper organization of such a provision can facilitate the creation of service cooperatives, and the effective use of logistical resources - production cooperation.

The presence in the agrarian sector of economy of Ukraine of a large number of farms is a sign of market reforms in the domestic agriculture, but the agricultural enterprises in need of state support and should, in our opinion, better to be cooperative. Nelep V. M. suggests that in Western Europe, farmers voluntarily united in cooperatives (typically industry), with the purpose of providing farmers with cheap and high-quality logistics resources, harvesting, storage, processing and realization of agricultural products and food products. The scientist gives the example of France, where 3,800 cooperatives unite $90 \%$ of the farmers. Through these cooperatives, farmers sell about $70-80 \%$ of the grains, and they export products (Nelep, 2015). Thus, cooperation of farmers and other small agricultural enterprises on a sectoral basis will provide an opportunity to reduce the cost of crops by improving logistics, rational use of resources and introduction of advanced technologies. In addition, cooperation in the field of grain processing and realization of grain products to increase of value added by eliminating intermediaries that currently buy from the manufacturers most of the grain.

In the framework of grain products subcomplex special attention should be paid to vertical and horizontal integration. Vertical integration creates conditions for improving economic ties between grain producers and processing enterprises of the subcomplex and also gives the opportunity to identify potential to increase value added at all stages of its creation. In this case, it is possible creation cross-sectoral associations, in which can to combine as producers of grain so and processing enterprises of grain and the manufacture of finished products. In such associations may enter enterprises for grain storage and wholesale distributors. An example here can serve agriholdings which are composed of the enterprise from production to sales of grain products. Such a model of management in grain products subcomplex AIC of Ukraine, as and cooperation, will promote to increase added value and does not require intermediary structures.

Of great importance in the increase of value added is a horizontal integration in grain products subcomplex of our country. In this case, the company shall retain legal and economic independence, but agree by the key performance indicators (e.g., production of grain or its processing, channels of sales) to increase and improve product quality. The result of such co-operation a balance is achieved the availability of grain products on the market, removes the threat of overproduction and reduce the selling price, more efficient use of logistical resources, and the result will been increase value added.

\section{Commodity pattern of exports and imports of grains}

One of the strategic objectives of grain products subcomplex is also the export of products with high added value. First of all, it will give the opportunity to fill the country's budget of foreign exchange income, to improve

Table 1

Commodity pattern of exports and imports of Ukraine for some groups (mln. USD)

\begin{tabular}{|l|c|c|c|c|c|c|}
\hline & 2010 & 2011 & 2012 & 2013 & 2014 & 2014 in\% to 2010 \\
\hline Total of exports & 50744,3 & 67594.1 & 67779.8 & 62305.9 & 53901.7 & 106.2 \\
\hline II. Plant products & 3949,9 & 5514,5 & 9173,1 & 8849,1 & 8739,1 & 221,2 \\
\hline in \% to total of exports & 7,8 & 8,2 & 13,5 & 14,2 & 16,2 & $+8,4$ p.p. \\
\hline of which: cereals & 2447,1 & 3604,5 & 6970,4 & 6351,7 & 6544,1 & 267,4 \\
\hline in \% to group II & 62,0 & 65,4 & 76,0 & 71,8 & 74,9 & $+12,9$ p.p. \\
\hline flour-grinding products & 80,7 & 111,0 & 105,1 & 137,0 & 124,4 & 154,2 \\
\hline in \% to group II & 2,0 & 2,0 & 1,1 & 1,5 & 1,4 & $-0,6$ p.p. \\
\hline IV. Finished food industry products & 2524,1 & 2902,0 & 3474,5 & 3500,5 & 3096,3 & 122,7 \\
\hline of which: preparations of grains & 253,9 & 338,4 & 394,9 & 412,3 & 390,1 & 153,6 \\
\hline in \% to group IV & 10,1 & 11,7 & 11,4 & 11,8 & 12,6 & $+2,5$ p.p. \\
\hline Total of imports & 60352,0 & 81040.5 & 83135.4 & 75834.6 & 54428.7 & 90.2 \\
\hline II. Plant products & 1526,9 & 1774,3 & 2366,1 & 2607,6 & 2031,6 & 133,1 \\
\hline in \% to total of imports & 2,5 & 2,2 & 2,8 & 3,4 & 3,7 & $+1,2$ p.p. \\
\hline of which: cereals & 145,4 & 219,5 & 248,9 & 306,5 & 366,7 & 252,2 \\
\hline in \% to group II & 9,5 & 12,4 & 10,5 & 11,8 & 18,0 & $+8,5$ p.p. \\
\hline flour-grinding products & 27,5 & 49,6 & 28,3 & 26,0 & 25,1 & 91,3 \\
\hline in \% to group II & 1,8 & 2,8 & 1,2 & 1,0 & 1,3 & $-0,5$ p.p. \\
\hline IV. Finished food industry products & 2488,9 & 3003,8 & 2938,8 & 3177,9 & 2601,8 & 104,5 \\
\hline of which: preparations of grains & 125,8 & 164,5 & 170,3 & 215,2 & 169,3 & 134,6 \\
\hline in \% to group IV & 5,1 & 5,5 & 5,8 & 6,8 & 6,5 & $+1,4$ p.p. \\
\hline
\end{tabular}

Source: calculated by the author using information (The statistical publication, 2015) 
to the financial condition of enterprises of grain products subcomplex and to significantly increase national income. At present, our country is increasing rapidly exporting mainly grains, not products. For the period of 2010-2014 sales volume of crops for export has increased by almost 2.7 times. In 2014, the figure was 6544,1 million USA, or $74.9 \%$ of exports of all products of plant origin (table 1 ). But, in 2014, group products of the milling industry in the export made up only $1.4 \%$.

The export of finished food products from grain during the study period increased by 1.5 times in 2014 totaled 390,1 million USA, but this figure is still insignificant compared to the export of grain. In turn, imports of grain for 2010-2014 in Ukraine also has tendency to increase, and imports of products the milling industry, on the contrary, decreased. Against the background of stability of indicators of the imports of finished food products, the export value of finished products of grain for the period 2010-2014 has grown by $34.6 \%$ and amounted to 169.3 million dollars USA.

Thus, Ukraine in recent years, increasing grain exports, as raw materials, is higher tempo, than its processed products and finished products of grain. This, of course, increases the value added in absolute value. But the increase in exports of products of processing of grain and products of grain would significantly increase this plan.

\section{Unity of the functions of strategic management of value added}

To implement informed us the main directions of strategic development of grain products subcomplex of AIC of Ukraine regarding the increase of the added value, it is necessary to improve strategic management of this process. We proposed a scheme of process of strategic management value added of grain products subcomplex of AIC of Ukraine shown in fig. 1.

Here we consider the strategic management of value added in subcomplex as the process in which the stages of realization of the strategic objectives have a certain sequence. First of all, it is necessary to analyze the current state of Affairs on the formation of value added in grain products subcomplex and outline the basic strategy. In our opinion, this should be the strategy of maximizing added value. To implement this strategy you need to choose a few of the purpose and justify the necessary amount

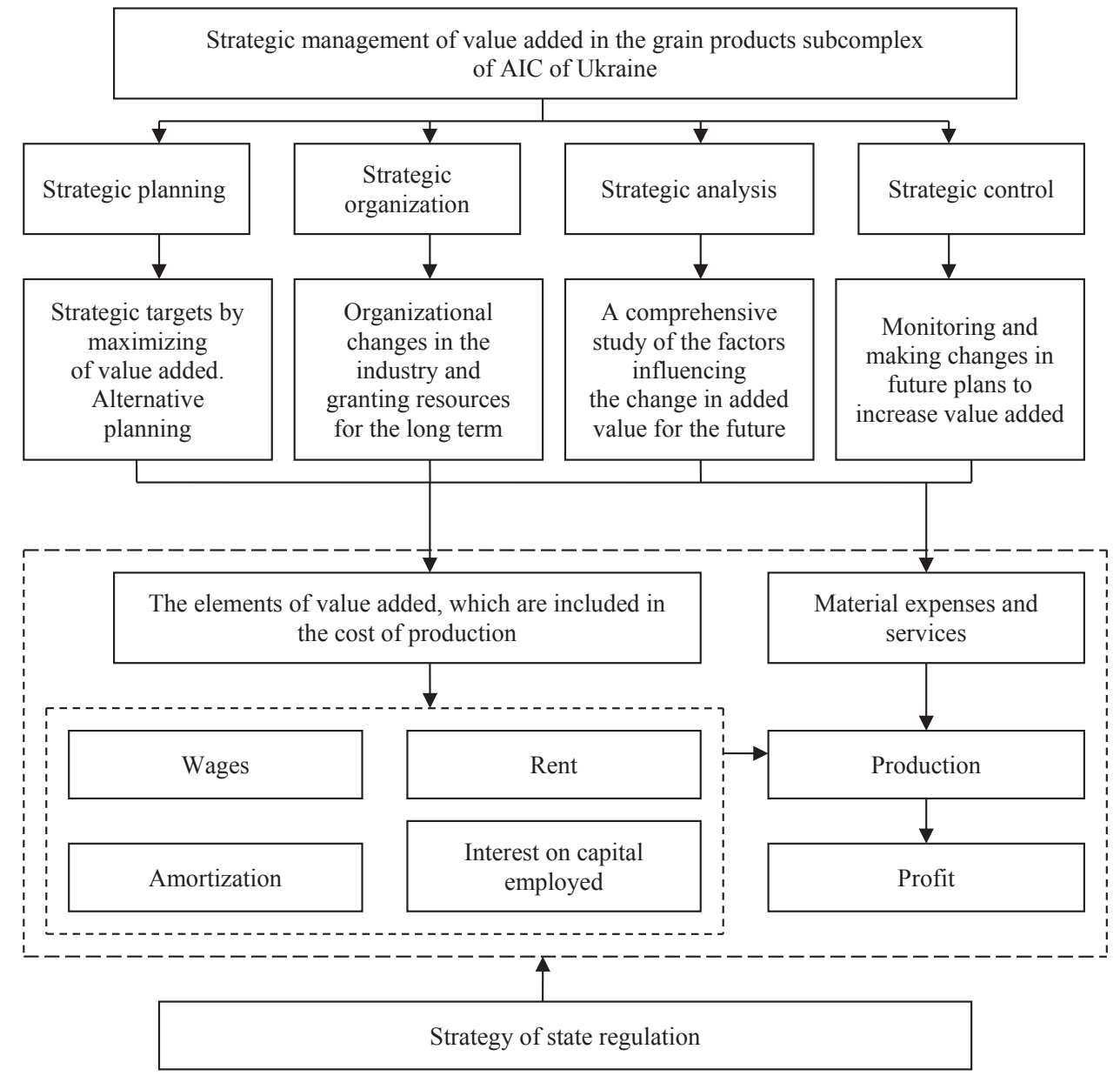

Fig. 1. Scheme of strategic management process of value added in the grain products subcomplex of AIC of Ukraine

Source: own research 
of resources. These objectives include: optimization of production to meet the needs of other industries in the grain and its processing and external demand; optimization of the structure of added value based on intersectoral concept of formation and so on. To these goals were successfully implemented, you need to build strategic planning. In addition, you need to take into account alternative options.

It is also necessary to provide for possible organizational changes in the sectors of the subcomplex and resources in the long term. It is important to outline the development of the necessary infrastructure, capacity expansion of processing industries, expansion of possibilities of the enterprises subcomplex in wholesale trade and export operations. This is a very difficult task, given the fact that the grain products subcomplex is an integral part of agro industrial complex and has production relations with enterprises from many sectors of the economy. That is, the grain products subcomplex can not develop in isolation, without taking into account the General principles and opportunities for the development of the entire economy of the state.

Permanent strategic control of the process of formation of added value will enable the adoption of timely decisions to adjust the corresponding actions in the direction of increasing added value. However, qualitative strategic control is not possible without adequate strategic analysis. The strategic analysis assumes a comprehensive study of the factors influencing the change in the value of value added for the future. Among the internal factors the growth of production through the introduction of scientifically based resource-saving technologies and sales of products at the most profitable channels, including for export. In addition it is necessary to analyze and external environment, namely: possible changes in the structure of Ukrainian economy and its separate branches; the demand for grain products in the domestic market; pricing policy for purchased inputs and for the products of grain products subcomplex; global trends in the production of grain and products of its processing and the demand for these products; export potential of our country in the grain sector. This analysis will provide an opportunity to justify future production and sales of grain products subcomplex and to identify ways of maximizing added value, in particular, and through the optimization of its structure.

In our opinion, it is necessary to pay more attention to the formation of such element of value added as wages. We must remember that only when employee connected with the means of production we can obtain the specific product, so it is very important that the employee had sufficient motivation to work. Financially motivated employee works more efficiently, therefore increases productivity, product quality, and ultimately increases profit.
To achieve greater of added value in grain products subcomplex, an important role plays the strategy development at the state level. State regulation of this process should be based on improving tax and customs legislation in relation to the industries of grain products subcomplex, as well as involves: an increase in state support of grain producers and processing industries; increase of government order and stabilizing of purchase prices; partial indemnification and reduction of prices of the purchased resources; expansion of leasing and others like that.

Consequently, the combination of strategic planning, organization, analysis and control at the level of enterprises of grain products subcomplex with the strategy of the state regulation will increase the profitability by increasing production and reducing specific material expenses. Also it is necessary to reach the rational structure of all elements of added value, which includes cost of production.

\section{Conclusions}

Consequently, strategic management of value-added in the grain products subcomplex of AIC of Ukraine should be aimed at increasing production, including high valueadded and its implementation in the domestic and foreign markets.

The basic directions of perfection of strategic management of value added in the grain products subcomplex of AIC of Ukraine we define as the following:

1. Strengthening vertical and horizontal integration of enterprises of all industries of grain products subcomplex. Thus, improve the control at all stages of added value formation.

2. Production cooperation and the creation of service cooperatives will contribute to increase added value and does not require intermediaries.

3. The introduction of resource-saving technologies and lower material costs that will provide to increase the profitability of production and will provide an opportunity to improve workers ' material interest in the outcome.

4. Production optimization in the grain products subcomplex tailored to the needs of internal and external market, stimulating the development of other sectors of the economy, which are use the grain. This will provide an opportunity to increase production and expand the range of products that will increase value added.

5. The increase in the share of production and sales of products with high value added, including for export.

6. Improving tax and customs legislation, strengthening state support for industries of grain products subcomplex. As a result of this expected reduction of production costs, the additional revenue in the process of implementation of products that have a positive impact on the value added. 


\section{References}

Ambrosov, V.Y. (2013). The market and the strategy of development of agricultural enterprises. Ekonomika APK, 10, p. 72-79.

Andriichuk, V.G. (2013). New types of agroindustrial formations within the framework of the national agrarian development strategy. Ekonomika APK, 1, p. 3-15.

Goncharov, S. M., Kushnir, N. B. (2009). Interpretative dictionary of the economist - Kiev, Centre of educational literature, $264 \mathrm{p}$.

Nelep, V.M. (2015). World and Ukrainian trends of agricultural development. Ekonomika APK, 7, p. 100-105.

The statistical publication (2015). "External trade of Ukraine in 2010-2014" [Electronic resource]. - Retrieved from: http://www.ukrstat.gov.ua

Zavadsky, Y.S., Osowska, T. V., Yushkevich, A. A. (2006). Economic dictionary. - Kiev, Condor, 356 p.

\section{Александр СВИтОВыЙ}

ЗЕРНОПРОДУКТОВЫЙ ПОДКОМПЛЕКС АПК УКРАИНЫ: СТРАТЕГИЯ УПРАВЛЕНИЯ ДОБАВЛЕННОЙ СТОИМОСТЬЮ

Аннотация. Целью статьи является обоснование путей усовершенствования стратегического управления добавленной стоимостью в зернопродуктовом подкомплексе АПК Украины. Методика. Исследование основано на монографическом методе и использовании статистической информации для подтверждения заключения о том, что стратегия управления добавленной стоимостью может быть основой для развития зернопродуктового подкомплекса. Результаты исследования показали, что одной из стратегических задач зернопродуктового подкомплекса есть рост производства на основе внедрения ресурсосберегающих технологий, а также экспорт продукции с высокой добавленной стоимостью. В пределах зернопродуктового подкомплекса особое внимание нужно уделить вертикальной и горизонтальной интеграции. Интеграция в зернопродуктовом подкомплекса АПК Украины, как и кооперация, будет способствовать увеличению добавленной стоимости и не требует посреднических структур, которые отбирают значительную часть прибыли у производителей. В достижении большей добавленной стоимости в зернопродуктовом подкомплексе важную роль должна сыграть выработка соответствующей стратегии и на государственном уровне. Государственное регулирование этого процесса должно основываться на совершенствовании налогового и таможенного законодательства по отношению к отраслям зернопродуктового подкомплекса, а также предполагает: рост государственной поддержкипроизводителей зерна и перерабатывающихотраслей; увеличение объемов государственного заказа и стабилизации закупочных цен; частичной компенсации и удешевления покупных ресурсов; расширениелизинга и томуподобное. Практическоезначение. Правильный выбор стратегии в управлении добавленной стоимостью в зернопродуктовом подкомплексе обеспечит АПК Украины интенсивное развитие. Это будет способствовать скорейшему переходу агропромышленного производства с сырьевого в производство с высокой добавленной стоимостью. Значение/оригинальность. Данное исследование поможет лучше изучить условия и факторы, которые оказывают влияние на увеличение добавленной стоимости в зернопродуктовом подкомплексе АПК Украины в стратегическом аспекте. 